\title{
Intersectionality and Kyriarchy: a framework for approaching power and social justice in planning and climate change adaptation.
}

\author{
Ms Natalie Osborne \\ Urban Research Program, School of Environment, Griffith University \\ n.osborne@griffith.edu.au
}

\begin{abstract}
In order to better understand existing inequality and injustice in our cities and spaces, and to understand how vulnerability to future impacts in the context of climate change is constructed and experienced, many scholars have noted that we need to incorporate multiple factors that shape identity and access to power and resources in our analyses, including race, class, gender, ethnicity and sexuality. Less widely acknowledged is the intersectionality of these factors; that specific combinations of these factors shape their own social position, lived experience, and thus affect access to power and experiences of oppression and vulnerability. To address emerging issues like climate change it is vital to find a way to understand and approach these multiple, intersecting axes of identity that shape how impacts will be distributed and experienced. This paper introduces intersectionality, a concept for understanding multiple, co-constituting axes of difference and identity, and kyriarchy, a theory of power that describes the power structures intersectionality produces, and offers researchers a fresh way of approaching the interactions of power in planning research and practice.
\end{abstract}

Key words: Kyriarchy; intersectionality; feminism; feminist geography; climate change adaptation; social justice; just city.

\section{INTRODUCTION}

Planning has always been a field divided. Planning can be visionary, a public good, reformist and a socially progressive activity (Frisch, 2002: 254; Steele et al., 2012: 67; Yiftachel, 1998: 395). Yet planning is "structurally accompanied by a more sinister dark side" (Yiftachel, 1998: 395). Planning can be a tool of capitalist exploitation; has defended white privilege at 
the expense of Indigenous people; can perpetuate social, economic, and environmental injustice; white, male and heteronormative hegemony; can privilege the interests of the rich over the poor; and has been used to exclude people on the basis of race, class, gender, ability, sexuality, and other Othered characteristics (Abu-Lughod, 1998: 235; Healey, 2006: 98; Sandercock, 1998a: 166; 2003: 44-5; Speak, 2012: 344; Steele et al., 2012: 67; Yiftachel, 1998: 397-8). This potential is what Sandercock refers to as the "noir history of planning" (1998a: 166) - planning that complies with and promotes the dominant culture and the silencing and oppression of marginalised groups (Doan \& Higgins, 2011: 9; Frisch, 2002: 254; Sandercock, 1998a: 166).

Planning has often ignored this noir history, and planning literature often neglects to acknowledge intersecting and numerous forms of oppression (Sandercock \& Forsyth, 1992: 51). Nieves argues that many still believe that issues of gender, sexuality, class and race are still "only marginal" in planning history (2002: 218). Indeed, Hendler critiqued planning ethics for being,

"slow to respond to contemporary developments in moral philosophy...[despite] the rise of feminist thinking within all branches of philosophy...almost no attention has been paid to the application or integration of feminist moral thought and planning" (Hendler, 1994: $115)$.

Despite this history, questions of power, difference, and social justice are enjoying something of a resurgence in contemporary planning discourse, largely, though not exclusively, through the emerging literature on the just city, just planning and climate-justice (see Campbell, 2006; Fainstein, 2000; Marcuse et al., 2009; Speak 2012; Steele et al., 2012). It could be suggested that this is due, in part, to a growing awareness about the social and spatial differentiation of climate change impacts, which is encouraging us to find ways to incorporate understandings of difference, variable vulnerability, power, privilege, and oppression into planning and 
adaptation work.

When it comes to understanding vulnerability in the context of climate change impacts and disasters, many scholars have noted that it is shaped by multiple factors, including race, class, gender, ethnicity, and sexuality. Less widely acknowledged is the intersectionality of these factors; that specific combinations of these factors shape their own social position, lived experience, and thus affect vulnerability. To begin to address emerging issues like climate change and to further our understanding of the "dark side of planning" (Yiftachel, 1998: 396) it is vital to find a way to understand and approach these multiple, intersecting axes of identity that shape experiences of power and place. Further, any planning activity aimed at reform, social, environmental and economic justice, inclusiveness, equity, or any other progressive goal, must understand the underlying structures that not only create the situations we are trying to address, but also the structures that constrain our own research, methods and actions. Quinn argued that in order to learn about places and people, we needed to better conceptualise the power relationships and structures that shape our spaces, that are "masked and made manifest along the multiple lines of race, gender, class and sexuality" (2002: 242). To do so, Quinn urges planners to read across disciplines (2002: 242).

The first part of this paper discusses intersectionality, a concept that emerged from critical race theory (Crenshaw, 1989, 1991) and has been further developed by feminist geographers and other fields of feminist and anti-racist inquiry. I argue that intersectionality could help planning scholarship understand and work with multiple, co-constituting axes of difference, and thus, vulnerability.

In order to place intersectionality in to the context of structural power, the second part of this paper explores the concept of kyriarchy. Kyriarchy is a theory about the nature of structural power developed in feminist biblical hermeneutics by Elisabeth Schüssler Fiorenza (1992). It 
has found some traction in academia outside of feminist the $* \log \mathrm{y}^{1}$, and has also been adopted in many feminist and progressive spaces outside of the academy. Kyriarchy, as a theory of power that dovetails with intersectionality, offers researchers interested in social and environmental justice a fresh way of approaching the interactions of power in planning practice, communities, space and places.

The final part of this paper explores how intersectionality and kyriarchy offer a conceptual framework that may inform planning scholarship; both in climate change adaptation work specifically and in work more generally concerned with issues of difference and power.

\section{INTERSECTIONALITY}

The term 'intersectionality' is attributed to critical race theorist Kimberlé Crenshaw (1989, 1991). It is a way to approach and understand intragroup difference and the existence of multiple axes of identity that may govern an individual's relationship to power.

Intersectionality emerged as part of the critique of universalising trends in identity politics, activism, and feminism; as Crenshaw argued, "The problem with identity politics is not that it fails to transcend difference...but rather the opposite- that it frequently conflates or ignores intragroup differences" (Crenshaw, 1991: 1242).

Women of colour have often been critics of mainstream/whitestream feminism, which, often through patriarchy, positioned men as universal oppressors and women as universally oppressed (Hill, 2008: 60; hooks, 2000b: 5-6). The experiences of white, heterosexual and middle-class women are not representative of all women's experiences, yet they have tended to dominate feminist discourse, and mainstream feminism has been reluctant to engage with

\footnotetext{
${ }^{1}$ I have adopted the convention of using an asterisk to avoid relying on gendered terminology, e.g. theology or thealogy, from feminist the* logy.
} 
race and other sites of oppression, to the exclusion and erasure of many women, especially women of colour (Bruns, 2010: 29; Collins, 1998a: 66-7; 2000: 5; hooks, 2000a: 56-8; Kartzow, 2010: 369). This also neglects the fact that many women of colour have also experienced oppression and exploitation at the hands of white women, and many feel that race is at least as great a determinant of their experiences as gender (Hill, 2008: 60; hooks, 1982: 12, 155; 2000b: 52). Feminists interested in issues of imperialism, colonialism, disability, gender identity, queerness and class have also critiqued universalising trends or claims in white, middle-class western feminism (Bruns, 2010: 29; Fuchs, 2008: 216; Hunt, 2001a: 743; Kang, 2005b: 287). As Kang wrote, "In our search for ties that bind women together, feminists themselves have sometimes overlooked crucial differences of race and class" (Kang, 2005a: 287).

Intersectionality addresses these critiques by disrupting the binary perspective that can occur when engaging solely in feminist theory, critical race theory, Marxist theory, or queer theory. Intersectionality acknowledges that a person may belong to multiple disadvantaged groups or identities and that this compounds and complicates their experiences of oppression in different contexts (Matsuda, 1991: 1191). It also acknowledges that one can simultaneously belong to both privileged and oppressed groups, and allows for the examination of both (Cole, 2009: 171). Similarly, because intersectionality accounts for the simultaneous experience of multiple axes of oppression, it illustrates the impossibility of clearly dividing lived identities from one another, as many "women from the nonmajority have been pressured to do" (Bruns, 2010: 30), and acknowledges that different identities may even seem to conflict with one another at times (Maddison \& Scalmer, 2006: 119).

Because these axes of privilege and oppression "overlap and interact" and mutually constitute each other, "none can be thoroughly analysed in isolation from its effect on the whole" (Bain, 
2011: 57), or else one risks unknowingly reinforcing these structures (Schneider \& Trentaz, 2008: 798). As such, intersectional theorists are particularly concerned with, "how these systems mutually construct one another, or...how they 'articulate' with one another" (Collins, 1998b: 63).

Further, it is important to note that intersectionality is not purely additive;

\footnotetext{
"a person's identity is not the sum total of the pain of each separate form of marginalization... Blackness is lived differently by women than by men, and being female is not a uniform experience across race, class, age, or disability" (Barager, 2009: 2).
}

Such an approach suggests some sort of base human from which Others deviate, and it also suggests a ranking and stacking of "fixed" difference, which is essentialist (Valentine, 2007: 13). An additive approach also neglects to recognise that, for example, a black woman does not experience oppression just as a black person and as a woman, but that the specific combination is a particular site of oppression.

Intersectionality emerged from critical race theory, but has been applied in many other fields of research, many of which are very relevant for planners and urban theorists engaged in climate change adaptation research or in other areas of social and environmental justice inquiry.

\section{Applications of Intersectionality}

Intersectionality has been drawn upon by scholars working in fields of interest to many planners, including urban renewal, spatial data analysis, experiences of and access to space and place, accessibility, health and dis/ability, homelessness, natural disaster research, and community development. This section discusses some of the approaches taken by researchers working with intersectionality, and some of the unique insights this approach has yielded, 
with a view to illustrating the utility of intersectionality in planning and climate change adaptation research, where, as yet, it has rarely been explicitly applied.

Specific approaches and applications Intersectionality has been applied in myriad ways. It has been used to explore how members of certain groups experience space and place, and how this experience is complicated by the presence of other axes of identity. For example, in one of the few explicit applications of intersectionality in planning research to date, Hoernig (n.d.) explored the differences amongst groups of recent migrants in establishing places of worship. Hoernig stated that intersectionality can help explain "many differences in minority place of worship development experiences", and argued that "skills, networks, and resources...social and economic variables" - factors shaped by intersectionality - affected the ability of different groups to solve problems (n.d.: 4). In a similar fashion, Hopkins (2008) also employed intersectionality to understand intragroup difference; Hopkins drew from intersectionality to understand lived experiences of body size, in the context of "other personal characteristics and spatial movements" (2008: 2120).

Intersectionality can help researchers address people and issues that have been neglected within a given discipline. Some authors have argued that geography has neglected the relationship between gender and other axes of identity, like class and age (Valentine, 2007: 10), has continued to marginalise women and members of minority groups (Dias and Blecha, 2001: 1), and that an intersectional approach may help address this. Similarly, Barager argued that an intersectional approach could help disability studies move past "its narrow focus on the experiences of white subjects with disabilities" (2009:1).

An intersectional approach does not only acknowledge the presence of multiple axes of oppression, but explores how they may relate to one another or co-constitute one another. As 
such, intersectionality provides a means to explore the interactions between "simultaneously linked identities and positions in the social hierarchy" (Frye et al., 2008: 619) in an integrated way, "theorize the relationship between different social categories" (Valentine, 2007: 10) and understand these relationships "as dynamic processes rather than as separate categories" (Watson and Ratna, 2011: 75).

An intersectional analysis can also help identify the voices being heard in research, and the voices being neglected. Couch (2011) employed intersectionality in her research on homelessness, noting that the experiences of homeless men tend to be written about more than the experiences of women, and that the added issues that young refugees face tend to be "virtually invisible" (2011: 40). This emphasises that even amongst very marginalised groups, there is heterogeneity of experience and treatment, in practice and in research, and that understanding these differences may be crucial for successful intervention and prevention.

These examples, selected for their particular relevance to planning and climate adaptation research, do not comprise an exhaustive list. There are other promising examples, but they are beyond the scope of this paper to detail.

Unique insights Intersectional approaches can yield insights that non-intersectional approaches may fail to reveal, or may even mask. Hopkins, for example, has used intersectionality to examine lived experiences of body type and size, demonstrating that the experiences of (self-identified) fat young people are relational, locational, and intersectional that who else they are, and who they're with, and where they are will affect how they experience their size $(2008 ; 2011)$. For example, one research participant, a young, gay, fat man felt that size and sexuality are linked; he felt especially bad about his size because he did not conform to the stereotype of the gay man as thin bodied (Hopkins, 2011: 1237). Another 
participant, a tall, fat, Indian woman felt that she did not conform to the expectations of women in her ethnic group - thus ethnicity and gender shaped her experiences of being tall and fat (Hopkins, 2011: 1238). As these findings demonstrate, intersectionality was vital to Hopkins' analysis and allowed findings to emerge that may not have if analysis had been focused on a single axis, such as body size alone. Similarly, researchers in disability studies have emphasised the importance of intersectional analysis in order to understand the lived experiences of people with disability, particularly given the relationship between people of colour and poor people and higher rates of disability (Barager, 2009: 3) and the fact that intersectionality shapes the ability of people with disability to access services (Haniff-Cleofas \& Khedr, 2005: 1).

Intersectionality has also yielded important insights in disaster management research. For example, Sultana discussed intersectionality in her paper on gendered vulnerability to flooding in Bangladesh, stressing that although gender matters in the context of natural disasters,

"Women are not a homogenous group, because intersectionality with class, caste, religion, age, etc. affects the resources, rights and responsibilities that any woman has. Similarly, while men may be dominant in largely patriarchal...they themselves are fragments by class, religion, educational status" (Sultana, 2010: 44).

Other scholars have found that although vulnerability to natural disasters is gendered, it is also shaped by ability, family type, cultural/racial group, and class (Fisher, 2010: 904-5; Neumayer \& Plümper, 2007: 552). Intersectional analysis becomes especially vital, as understanding these factors will be critically important for successful interventions in the face of increased intensity and frequency of natural disasters due to climate change. In her analysis of urban activism against gentrification, Lee employs an intersectional lens; she posits that race and gender have been concealed in urban theory, and that class, race, and 
ethnicity have been concealed in women's activist movements (Lee, 2007: 382). Ergo, an intersectional lens is needed if we are to understand the complexities of inequality in urban phenomena, like urban renewal, as well as how the community in her case study were able to successfully challenge urban renewal processes despite their marginality from politics and planning (Lee, 2007: 387). For example, she argues that many researchers overlooked the role of women of colour in politics "because much of what they say and do fails to fit prescribed Western, mainstream feminist perceptions of the nature and forms of activism" (Lee, 2007: 394), just as many researchers overlook the role of feminine-coded spaces in organising and community building, such as gatherings and meetings in kitchens and cafes (Lee, 2007: 400). These findings typify the value of intersectional analysis in geography, planning and community-based research.

Despite the relevance and utility of intersectionality, it has not been widely applied in planning research to date. Milroy touches on intersectionality in discussing how class and race have "magnifying effects" on women's experiences of oppression (1991: 4), and Listerborn observes that in planning, "Post-colonial theories are virtually absent in planning practice, and issues of gender and racist discrimination are seldom related to each other" (2007: 64), but there are few other mentions. It is not that planning theorists and researchers are unaware of intersectional issues and identities, but this conceptual framework, developed in other fields, does not seem to have been brought across to planning theory. However, the language and conceptualisation of intersectionality and of kyriarchy, explored in the following section, offer much to planners and to adaptation researchers. There is much to be gained by building on the work of scholars in different, but related fields, to help us grapple with issues of power, justice, access, and vulnerability in our cities and spaces. 


\section{KYRIARCHY}

Kyriarchy is a hermeneutical concept created by feminist the*logian Elisabeth Schüssler Fiorenza, from kyrios, which means 'master', and archein, which means 'to rule' (Bobel \& Kissling, 2011: 122). Kyriarchy describes a system of "interlocking structures of domination" (Schüssler Fiorenza, 1992: 8). Like Crenshaw, Schüssler Fiorenza critiqued mainstream, Western feminist theory for focusing solely on gender difference, as it "masks the complex interstructuring of patriarchal dominations inscribed within women and in the relationships of dominance and subordination between women," (Schüssler Fiorenza, 1992: 123) as well as failing to acknowledge the role of elite, white women and Christianity in helping perpetuate oppression (Schüssler Fiorenza, 1992: 123).

Kyriarchy was Schüssler Fiorenza's way to help address this issue in feminist theory and discourse. It is a development on patriarchy (meaning rule of the father), designed to acknowledge that gender is not the sole determinant of one's access to power; it refers to rule of the master, where the master is not only a father/patriarch, but is an otherwise "elite" man (Abrahams, 2005: 26-7; Schüssler Fiorenza, 1992: 8, 117). Patriarchy, as an analytical tool, ignores intersectionality - it ignores the interconnections between other power structures (including race and class) and gendered oppression, and, in doing so, reinforces binary ways of thinking that erase the complexity of experiences (Arrazola, 2011: 66; Moon, 2008: 129). Kyriarchy complicates the hierarchy and decentres gender as an analytical and epistemic category (Power, 2001: 70); it expands on patriarchy to incorporate the multiple, intersecting and co-constitutive structures of power and oppression that shape any individual's experiences (Aquino, 2007: 25; Bruns, 2010: 32), and that intersectionality instructs us to account for. As Schüssler Fiorenza herself, drawing from bell hooks, expressed, kyriarchy helps us understand how interlocking systems of oppression, "criss-cross the subjectpositions that the politics of domination offers to individuals" (Schüssler Fiorenza, 1992: 
123). Indeed,

\begin{abstract}
"While patriarchy signifies domination of all men over all women, kyriarchy helps us understand the complex power relations through which differences among wo/men are produced as well as the discursive construction of the subject as positioned across multiple axes of difference" (Kim \& Whitehead, 2009: 6).
\end{abstract}

Exactly what these other axes of difference are vary from scholar to scholar as well as according to social/spatial/temporal location, but they may include race, ethnicity, religion, class, sexuality, gender, gender identity/expression/conformity, relationship status, ability, body type/size, age, colonial status, national identity, and more (Kim \& Whitehead, 2009: 6; LeFrançois, 2013: 1; Lelwica, Hoglund, \& McNallie, 2009: 21-2; Schüssler Fiorenza, 2005: $115)$.

In finding a way to conceptually grapple with multiple, intersecting and co-constitutive structures of power and oppression, kyriarchy also accounts for relative privilege. As bell hooks argued, white women can be privileged in whiteness and oppressed in gender, and white women can "act as oppressor or be oppressed" (2000b: 16). Kyriarchy is present even on the 'margins'; for example, some queer spaces and movements have been criticised for privileging white men and gay male issues over others (Doan \& Higgins, 2011: 8; Hunt, 2001b: 213; Walter, 2010: 1). Kyriarchy helps us understand this phenomenon; that even in a marginalised community, whiteness, class and other power structures still exert influence, and it provides a way to acknowledge these intersectional factors in our analysis of power (Isherwood, 2011: 161) and gives us a way to conceptualise intragroup difference.

It must be understood that kyriarchy does not conflate and collapse all structures (like patriarchy, colonialism, racism, heterosexism, etc.) into a single structure. Although there are common patterns and characteristics shared by oppressive structures, they are not all the same 
and do not all function identically (Matsuda, 1991: 1188). They are, however, interlinked, interactive, co-constituting, and they draw from one another to support their own power (Matsuda, 1991: 1189). Different structures of oppression are not, "synonymous", as bell hooks put it, "they are linked and yet differ" (hooks, 1989: 125). Further, the way that an individual experiences a certain structure will always be complicated by the other structures present in their lives - by intersectionality.

\section{Applications of Kyriarchy in The *logy}

In academic settings kyriarchy has been employed largely in feminist the*logy. Elisabeth Schüssler Fiorenza applies kyriarchy in a number of ways in her the*logical work. She uses it as a hermeneutical tool, applies it in discussions of power, knowledge and authority both in biblical texts and in contemporary contexts, such as in theological education and pedagogy (Schüssler Fiorenza, 1992: 190-2). Following from this, Masenya, like many feminist the*logians who engage with kyriarchy, challenges kyriarchy-supporting interpretations of religious texts, arguing that alternative readings are possible and can liberate those oppressed by kyriarchal structures (Masenya, 1995: 150).

In addition to the use of kyriarchy as a hermeneutical tool for the analysis of religious texts, scholars have used kyriarchy to conceptualise power in religious structures and organisations and the relationship between religion and other power structures. For example, Kienzle and Nienhuis argue that the kyriarchal systems in place during the early period of Christianity substantially shaped the Christian church and doctrine - they argue that early Christians were actually unusually and dangerously egalitarian (2001: 38). Encouraging submission (particularly of women and those belonging to "lower" classes) and ritualizing sacrifice and suffering arguably helped early, marginalised Christians fit in, but this has led to kyriarchal structures being reinforced by the churches (Kienzle \& Nienhuis, 2001: 38). Similarly, many 
in the womenpriest movement have acknowledged how oppression in the Roman Catholic Church is constructed not only along gendered lines, but also that other marginalised groups, including lesbian, gay and bisexual people, and people of colour, are oppressed and excluded from positions of power (Moon, 2008: 120). These applications indicate that kyriarchy may be able to shed light on hegemony and power in planning scholarship and practice, and highlight the potential to use kyriarchy to problematise, reread, and reframe the texts and messages at the heart of planning.

Analysing who is absent from discourse and why is a particular concern for planners involved in public engagement work or community based research. Kyriarchy has been used for this sort of analysis - for example, Crosby, in her analysis of religious 'Mommy Blogs', found that not only are women's blogs undervalued generally, the mommy blogs that do gain attention are generally written by white, heterosexual, partnered, thin and middle class women and that this model of motherhood is generally privileged over other models and the experiences of other women (Crosby, 2011). This analysis of how kyriarchy confers legitimacy and attention along intersectional lines is instructive to researchers seeking to analyse and evaluate how inclusive and comprehensive their own research and processes are.

\section{Applications of Kyriarchy outside of The* $\log y$}

There has been limited scholarly application of kyriarchy outside of feminist/womanist liberation the* $\operatorname{logy}$. It has been used by Lelwica et al to explore the colonial dynamics and complexities of 'thinness', including how privileged women are also implicated in the oppression of less privileged women through a "bodily ideal constructed through...racialclass-cultural privilege" (2009: 22). Kyriarchy has also been applied in mental health research, in a study highlighting the kyriarchal power of psychiatry as an institution, and how 
heterosexism interacts with other "socially disadvantaged subjectivities" (LeFrançois, 2013: 1). These applications are worth noting because they demonstrate the successful application of kyriarchy beyond the* logy, successfully grapple with multiple intersections of identity, and illustrate some of the ways kyriarchy perpetuates itself.

\section{POTENTIAL IN PLANNING AND ADAPTATION WORK}

By proposing that planners explore kyriarchy and intersectionality, I am not urging anything that other planning theorists have not already alluded to. Many planning scholars have drawn from other areas of social justice scholarship to argue for an emancipatory planning practice, one that challenges hegemony, furthers equality and seeks meaningful empowerment for participants in planning processes (Connolly \& Steil, 2009; Friedmann, 2003; Miraftab, 2009; Peattie, 1994; Sandercock, 1998a, 1998b). For example, Hendler, drawing on Sherwin, discusses a development in feminist ethics expanding its focus to include other axes of oppression and emphasises the importance of questioning broader systems and structures (Hendler, 1994: 120). She states that “A feminist approach to planning ethics would...[focus] on community and disadvantaged persons" - where "disadvantaged" referred to all oppressed people, including "women, visible minorities, the disabled, and others who through no fault of their own are not privileged members of the planning discourse" (Hendler, 1994: 123). We can see how the language of kyriarchy and intersectionality could help conceptualise who and how people are isolated from planning discourse.

Others have urged planners to study kyriarchy and intersectionality, albeit without the specific language or framework. Rankin argued that very little planning theory, "seek[s] out the agents of revolutionary social change" (Rankin, 2009: 219), and that we need to better interrogate the "processes of imperialism, racialization, male domination and the expansion 
of capital" in planning theory (Rankin, 2009: 220). Rankin also suggests that "planning action rooted in reflexively querying positionality might play a catalytic role and help build the political constituencies needed for claiming the right to the city" (Rankin, 2009: 227). I would argue that intersectional and kyriarchal analysis could aid the interrogation of processes and structures Rankin calls for, as well as providing a fresh way of approaching positionality.

Fainstein and Servon note that:
"We recognize that gender is not the only lens that allows us to look at planning and policy issues from another perspective. Race and class are other ways of sorting people, and the resulting groupings show similar kinds of power differentials...Gender is a necessary but not sufficient tool for understanding how decisions are made and for conceptualizing a better way to make these decisions. Our interest in gender reflects our concern about oppression and disenfranchisement and our belief that the world would be a better place if we could move toward a situation in which planning and policy decisions automatically incorporated these other perspectives" (Fainstein \& Servon, 2005: 6).

Fainstein is also one of the key authors in the just city movement, and she too has argued that our research should "concern itself with redressing disadvantage as it affects groups" and that this focus could help us "have a better handle on power relations and social structures" (2009: 29). Fischer calls on us to ask, "who is privileged and who is marginalized by existing forms of governance" (2009: 64) and Healey argues that because of power relations and systems of privilege (what I refer to as kyriarchy), we each inherit a, "different mix of assets, burdens and hurdles, depending on where we start out in life" (2006: 120). The benefit of a kyriarchal conception of power and an intersectional understanding of identity is that it gives us way to acknowledge that person may sit across any number of different identity groups and that difference exists within any given identity group. Further, it gives us a more nuanced understanding of the power differentials at play, and provides a conceptual framework for 
approaching the questions outlined by these scholars.

Nieves identifies several barriers to this sort of research in planning. These include the necessity for research around "interlocking systems of oppression" to be inter- and multidisciplinary, as well as the hegemony and privilege within academy, resulting in a lack of research and career support for intersectional studies and researchers who are "committed to understanding the world around us in a more complex and challenging manner" (Nieves, 2002: 216). There is also resistance around moving away from traditional methodologies towards ones better able to study intersectionality (Nieves, 2002: 215), and a reluctance to move beyond simple binaries to a complexified understanding of power and oppression (Nieves, 2002: 218). Despite these barriers, a number of planning theorists have identified the need for an improved way to conceptualise difference, identity, marginality, positionality, and power, and perhaps the body of work around kyriarchy and intersectionality can help address that gap and aid our research agendas in a number of ways. The remainder of this section explains the theoretical usefulness of a framework that integrates intersectionality and kyriarchy, and outlines a number of areas where this integrated framework could be applied.

\section{The benefits of an integrated framework}

There are a number of benefits to employing intersectionality and kyriarchy together as an integrated framework. The immediate benefit to integrating intersectionality and kyriarchy is for the conceptual clarity the two offer when used together. Kyriarchy, as outlined previously, describes a multi-faceted power structure, and allows us to understand power as a function of multiple axes of identity and privilege rather than focusing on one (e.g. as with gender and patriarchy or race and white supremacy), which is inadequate for understanding the complexity of lived experience. Simply put, kyriarchy describes the power structures intersectionality creates; in turn kyriarchy creates intersectional identities, and lived 
experiences determined by multiple, sometimes conflicting, axes of identity. Where 'patriarchy' is understood as the force shaping and perpetuating gendered oppression, 'kyriarchy' is understood as the structure shaping intersectional oppression. Ergo for a conceptual framework to comprehensively and clearly incorporate an understanding of the multifaceted nature of privilege and marginality, both are best employed. An integrated framework also improves our capacity to examine individual experiences of marginality and vulnerability within the context of structural power. An intersectional study that draws from kyriarchy to establish its theory of structural power can demonstrate how intersectional identities, and in turn, lived experiences, are produced and experienced through kyriarchy. A kyriarchal study may draw from intersectionality in order to understand how the experiences of this structural power are shaped by the intersection of identity groups at the individual level.

As mentioned in the introduction of this paper, the literature on climate change vulnerability and adaptation is increasingly noting the complex ways that risk and vulnerability are distributed and experienced. An integrated framework would offer a promising way to expand on the work of Fisher (2010), Neumayer \& Plümper (2007) and Sultana (2010). They found that vulnerability to natural disasters is gendered, but that this vulnerability is also shaped by other factors, including race and class. An integrated framework provides a way to interrogate the lived experience of these intersectional identities in the context of risk and vulnerability, and how the combination of different axes might be ameliorating, exacerbating or creating entirely new experiences of risk and vulnerability. This interrogation may also help us to understand how these identities have been constructed - the nature of their institutional and structural power. In order to address this issue of differential vulnerability and exposure to risk, it is vital to understand both the complex, intersectional lived experiences of individuals and how those experiences are shaped by structural power - by 
kyriarchy. The integration of intersectionality and kyriarchy provides a framework for this kind of analysis.

\section{Intersectionality and kyriarchy as a tool for understanding and conceptualising vulnerability}

The imminent threats of climate change and peak oil have challenged planners to undertake risk assessments and vulnerability analyses and to understand how these global threats are likely to play out at a regional or local scale. Planners, urban researchers, policy academics and makers, have all been challenged to conceptualise "risk", and "vulnerability", in a way that aids our ability to plan adaptive measures against likely impacts.

There is a lot of data to suggest that today's marginality is tomorrow's vulnerability to the impacts of climate change and peak oil (Dilling \& Moser, 2007: 7; Donner \& Rodríguez, 2008: 1090; Fisher, 2010: 910; Levine, Esnard, \& Sapat, 2007: 5; Neumayer \& Plümper, 2007: 551; Steele et al., 2012: 68; Thompson, 2009: 216; Tompkins \& Adger, 2003: 3; Verick, 2009: 3; Yamin, Rahman, \& Huq, 2005: 2). As Fisher stated,

\footnotetext{
"Although a disaster begins with or is triggered by a natural event, its effect upon society is grounded in the social system in which it takes place...An individual's vulnerability is rooted in social relationships, determined by a number of factors, such as gender, ethnicity, class, age, and disability" (Fisher, 2010: 904).
}

Donner and Rodríguez (2008) note that vulnerability and the social forces shaping vulnerability are multifaceted and dimensional. They state that risk perception is not only shaped by gender, but by race and ethnicity also, which complicates our understanding of how identity and social position shape vulnerability (Donner \& Rodríguez, 2008: 1106-7). Steele et al. describe the issue of 'climate justice' - the relationship between social justice and experiences of and exposure to climate change as, "the moral and ethical imperative of 
the times" (2012: 72).

Strongly related to this is the field of environmental justice, a field that investigates the disproportionate exposure to environmental risk and pollution borne by people who belong to marginalised groups. However, intersectional theory itself has not often been explicitly applied (Kirk, 1997), and certain axes have received considerably more attention than others (Buckingham \& Kulcur, 2009: 660, 663).

Intersectionality and kyriarchy can help conceptualise both contemporary vulnerability and exposure to environmental risks and vulnerability to future threats, as well as help to expose the power structures shaping vulnerability. The intersectional work on disaster management, homelessness, and migration will be particularly instructive in this regard (see Bastia, 2011; Bürkner, 2011; Couch, 2011; Fisher, 2010; Neumayer \& Plümper, 2007; Sultana, 2010). It is important to make gender, race, and other marginalised identities explicit in adaptation research, because when it is explicitly absent from consideration, it is implicitly present and affects this work in unacknowledged ways (Preston et al., 2011: 755).

\section{Intersectionality and kyriarchy as epistemological tools}

One key limitation of social and adaptation planning is that planners and other professionals involved often belong to quite privileged groups. This can limit our ability to understand and truly further the causes of marginalised peoples, partly due to the fact that "the people that the system directly benefits are unaware of how the world is being shaped by their dominance, for their continued dominance" (Spinks, 2010: 11). It can be difficult to see, let alone study, structures that privilege has rendered invisible, partly due to self-interest, as "to some degree their privilege depends on the continued oppression of others" (Young, 2005: 96). Further, planning scholarship and practice is not only embedded in the individual privilege of the 
planner/researcher, but in the same systems that have created the problems these planners may be seeking to address - it is "a product of the society it is called upon to change" (Marris, 1998: 10). Drawing from Audre Lorde (1984), we may find ourselves, in vain, trying to dismantle the master's house with the master's tools.

This is a key way that an integrated framework can aid in planning work. Kyriarchy and intersectionality help us reflect on our place within the kyriarchal web, where we sit on various axes, understand our own privilege and place the way we experience marginality as individuals as part of a broader context of systemic injustice. They give us a framework to help us look for perspectives, injustices, omissions, that our privileged positions may have prevented us from seeing and help us reflect critically upon our own positions and privilege, how those patterns shape our identities, and how we relate to our studies and our work (Buell, 2010: 319; Kartzow, 2010: 370).

By giving us a new way to understand the relative positions people with certain mixes of identities occupy in society, and the different life experiences they have, kyriarchy and intersectionality also creates a space for us to consider how we can incorporate other knowledges. Kyriarchy is present in, and reproduced by, the knowledge systems (especially universalising knowledge systems) that are privileged in our society (Aquino, 2007: 14, 17), thus an awareness of kyriarchy can help us problematise this privileging as well as strengthen the argument for the use of alternative research methodologies. The understanding that privilege and power can render certain structures and systems invisible ties in with feminist standpoint theory. Standpoint theorists argue that those experiencing a phenomena have a direct and unique access to knowledge of it - those who are oppressed are best positioned to inform us about the nature of privilege and oppression (Jaggar, 2004: 57; Sismondo, 2001: 14952; Walby, 2001: 486; Wylie, 2003: 26). Intersectionality also ties in with feminist 
standpoint theory, in that "marginalized subjects have an epistemic advantage" (Kartzow, 2010: 370) in intersectional research.

\section{Intersectionality and kyriarchy as a hermeneutical and analytical tool}

Kyriarchy suggests a number of different methodological tools and applications. When conducting historical analysis, one questions "a source's relationship to kyriarchal structures and kyriocentric ideology" (Bain, 2011: 57), a technique demonstrated by Masenya (1995), Kienzle and Neinhuis (2001), and Moon (2008), that could be similarly applied to contemporary document analysis in planning scholarship.

Hill argued that "...stories of injustice only become powerful when they are arranged into communal patterns" (2008: 64), and intersectionality and kyriarchy, combined with case study research, interviews using storytelling techniques or building oral histories, can help us understand, track, and build those patterns. Matsuda, in her discussion of intersectionality, implores us to "ask the other question" (1991: 1189). She states that,

\footnotetext{
"When I see something that looks sexist, I ask, 'Where is the heterosexism in this?' When I see something that looks homophobic, I ask, 'Where are the class interests in this?"” (Matsuda, 1991: 1189).
}

This is an important task for all planners concerned with social equity issues and justice in cities, planning and adaptation, because it requires us to hunt for "hidden" structures of oppression and it reveals the interrelationships and intersections that constitute kyriarchy.

\section{Embedding intersectionality and kyriarchy as a way to approach a more collaborative planning and research process}

Friberg argues that supplementing planning process by tacking on issues of gender, race, etc. is insufficient (2006: 284). Rather, to do so effectively we need "a new starting 
point...rewriting the subject using new concepts and introducing new categories of analysis such as gender and race" (Friberg, 2006: 284). Fainstein and Servon argue that, "the world would be a better place if...planning and policy decisions automatically incorporated these other perspectives" (2005: 6), and in developing the climate-just city conceptual framework, Steele et al. argue that we must ask "'who dominates?' 'who benefits?' and 'who gets left behind?"' in urban planning processes (Steele et al., 2012: 80). Young argued that we need "specific representation for oppressed groups" if we are to disrupt the privileging of certain voices and groups in the policy and public engagement process (2005: 96). An understanding of intersectionality and kyriarchy can lead to a more comprehensive picture of oppressed groups and may enable a process "shape[d] from the outset" by diverse voices, which is, as Hunt says, a key goal of modern feminism (2001a: 743). Further, as demonstrated by Crosby (2011), kyriarchy can be employed in order to help identify who is speaking, and who is absent. The complexified understanding of identities, marginality, privilege and power that intersectionality and kyriarchy offer us can help us achieve meaningful inclusion of diverse voices and avoid the tokenism that can occur when, for example, one woman is expected to be representative of all women, etc.

\section{Exploring the role of space and place in intersectionality and kyriarchal power.}

The role of space and place in the production and experience of kyriarchy and intersectionality is a significant, but under-researched area. Moxnes, a theologian writing about locative intersectionality in Galilee in the time of Jesus highlights this importance:

\footnotetext{
"Social relations and structures always happen in place. Place is a multifaceted category, it is locative and topographical as well as mental and ideological. Moreover, places are not fixed in their identities; they are always open for interpretations...A locative intersectionality investigates how individuals and groups get placed, placed themselves and also place others, both physically, structurally, and rhetorically" (Moxnes, 2010: 392).
} 
There has not been a great deal of exploration of the role of space and place in intersectionality (Valentine, 2007: 14) or kyriarchy. Wright (2010), Moretti (2008), Watson and Ratna (2011), and Hopkins $(2008,2011)$ have begun negotiating these waters, exploring how intersectionality shapes experiences of place and how space can reinforce kyriarchal institutions, but urban and planning theorists are well positioned to improve our understanding of how intersectionality and kyriarchy are produced and experienced in place.

\section{CRITIQUES AND CAUTIONS}

Kyriarchy and intersectionality have their critics and critiques. For example, Brown states that some geographers have rejected intersectionality as outlined by Crenshaw, arguing that it "actually dangerously separates race and sexuality...the metaphor of the intersection presumes and empirical or conceptual separation of the two" (2011: 543). I take the point that the imagery conjured up by the term 'intersection' does not necessarily convey the blurred boundaries and mutual constitution of various 'roads' that intersect, but the explanations and research of intersectional theorists make those characteristics quite clear.

Kyriarchy, like other frameworks that seek to account for multiple axes of difference and identity or that destabilise universalising categories have also been critiqued. The rise in postmodernism and poststructuralism has made it difficult for those with emancipatory goals because of the loss of universalising categories like 'woman' (Derickson, 2009: 896), and it might be feared that by trying to include more, or develop a more complex and non-binary understanding of power and oppression, we may lose relevance and pertinence. Campbell noted, "Recognition of the oppressive and exclusionary capacity of homogenizing models of identity leaves planners floundering in a sea of difference and fragmentation” (2006: 92). 
However, I would argue that kyriarchy and intersectionality actually help to overcome some of the challenges presented by postmodernism; they supply us with a way to acknowledge intragroup difference and acknowledge multiple structures of oppression and privilege without essentialising, over-generalising or homogenising oppressed peoples' identities. Kyriarchy reminds us that subject-positions “criss-cross” (Schüssler Fiorenza, 1992: 123), that we cannot expect one to speak for all members of a group they may belong to, that getting a diversity of participants even within a particular identity group can be necessary, and intersectionality warns us not to ignore the presence of other structures of oppression lest we propagate them inadvertently. Similarly, by drawing from feminist standpoint theory, kyriarchal and intersectional theorists can also negotiate the epistemological challenge of a world diversely experienced by acknowledging that "marginalized subjects have an epistemic advantage"(Kartzow, 2010: 370).

It might also be argued that kyriarchy and intersectionality make things too complex and are thus impractical in primary research. On this, a number of kyriarchal/intersectional scholars have acknowledged that sometimes it is helpful, meaningful or necessary to focus on a particular identity group/axis (Baines, 2010: 129; Hunt, 2001b: 220; Watson, 2009: 6) Baines dubs this, "strategic essentialism" (2010: 129). Crenshaw, in a seminal paper introducing intersectionality, focused on race and gender, noting that class and sexuality "are often as critical", and that the selection of race and gender, "only highlights the need to account for multiple grounds of identity when considering how the social world is constructed" (1991: 1245). As mentioned earlier, kyriarchy does not conflate or collapse all structures of oppression into a single, undifferentiated structure; different structures can have "distinct functions" that shape how they operate (Marchal, 2006: 15) and although the structures interact, share similarities, and co-constitute each other, at times it is prudent to engage in strategic essentialism. Colonialism operates quite differently to heterosexism (as 
one example), and so it can be useful to foreground a particular axis when seeking to understand how it functions and is perpetuated. Sometimes it is necessary to claim a single axis or identity to spur political action, however, "the identity must always be questioned to stop it from become a static entity within a chain of hierarchized identities" (Watson, 2009: 6). Foregrounding a particular axis - like gender in natural disaster vulnerability, or a particular intersection, e.g. race and gender in disaster vulnerability, may be informative or provide a way into the issue. Employing an integrated framework can help studies engaging in "strategic essentialism" to recognise it for what it is - a flawed but sometimes necessary categorisation, but one that can only present part of the picture. Kyriarchy and intersectionality require that while foregrounding one axis we should still attempt to understand how other axis intersect and interact with that axis, especially when it comes to researching the lived experiences of people, which will always be complicated by the presence of other axes of privilege and oppression. Even in its most basic form, simply acknowledging that an identified axis is not the only one at play (even if it is the only one being directly studied) can overcome some of the universalising and erasing tendencies that can otherwise occur.

Another issue raised by Brown is that geographies of sexuality have tended to privilege intersections of gender, race, and class, to the exclusion of intersections of age, religion, disability, and other identities (2011: 545). This is undeniable, but it is an argument for more intersectional work, not less. The work of Hopkins $(2008,2011)$ referred to earlier in this paper, on the intersectionality of experiences of body size is particularly instructive in this regard. 


\section{CONCLUSION}

Intersectionality and kyriarchy gives us a new, more nuanced language that better reflects the complexity of power, social relationships, and vulnerability. This language better enables us to talk about specific experiences of marginality without erasing the experiences of others, or rendering invisible the shades of difference of experience that occur when no group is a monolith. It means,

"challenging those in power, those whose voices are validated by the kyriarchy, to temper their speech and discourse, to make their truth claims in a more tentative manner, creating an openness for dialogue and other perspectives" (Powell, 2011: 29).

Combining these two concepts in an integrated framework provides us with a new means to explore individual, lived experiences within the context of structural power, and the ways that structural power is constructed and perpetuated. In planning and climate change adaptation kyriarchy and intersectionality may help to develop a more complex understanding of marginality, oppression, and vulnerability. By improving our understanding of the way disasters and other climate change impacts are experienced, our responses may be improved. A better understanding of other phenomena that are likely to be exacerbated by climate change, such as migration, ill health, and homelessness, will enable better planning and preparation.

This integrated framework can also help us grapple with social justice issues in our cities, and explore issues of access, power, and rights to space in a more nuanced way. It can help,

\footnotetext{
"bring together discussions regarding ethnicity, class, gender, and age....and look at the relationship between the various categories, suggesting a theoretical vocabulary that speaks about hierarchy and social categories in a more complex way" (Kartzow, 2010: 365) (emphasis in original).
}

It raises questions about how we produce and privilege knowledge, it urges us to explore 
alternative research methods and theories "rooted in processes of social change and propose emancipation and justice as the primary objectives of knowledge" (Aquino, 2007: 17). Intersectionality and kyriarchy challenge us to reflect on our own privilege, and how we can be privileged or marginalised according to context and what that might mean for our research. It reminds us to ask "the other question" (Kartzow, 2010). Kyriarchy as a hermeneutical tool can give us a new way to look at old data, as feminist the*logians have used it to re-read religious texts. Finally, perhaps the use of a framework developed in feminism, feminist the*logy, womanism, and critical race theory will widen the channels between planning scholarship and those in different fields with shared, emancipatory goals, and promote the interdisciplinarity that is so often called for in planning, social justice and climate change research.

\section{ACKNOWLEDGEMENTS}

I would like to thank my supervisors Dr Diana MacCallum and Dr Catherine Howlett, and colleague Dr Deanna Grant-Smith, for their support for this work and their detailed feedback. I would also like to thank the community at the blog Shakesville, especially founder and manager Melissa McEwan, for inspiring this work by first introducing me to kyriarchy and intersectionality and how these concepts work with one another, and for providing daily support, encouragement and inspiration for feminist analysis. I would also like to offer my thanks to the editors and to the anonymous reviewers of this paper for their constructive feedback and support.

\section{REFERENCES}

Abrahams, L. A.-L. (2005). A critical comparison of Elizabeth Schüssler Fiorenza's notion of Christian ministry as a 'Discipleship of Equals' and Mercy Amba Oduyoye's notion as a 'Partnership of both men adn women'. Magister Theologae, University of Western Cape, Cape Town, South Africa.

Abu-Lughod, J. (1998). Civil/Uncivil Society: Confusing Form with Content. In M. Douglass \& J. Friedmann (Eds.), Cities for Citizens: Planning and the Rise of Civil Society in a Global Age. Chichester: John Wiley \& Sons Ltd., pp. 227-237.

Aquino, M. P. (2007). Feminist Intercultural Theology: Toward a Shared Future of Justice. In M. P. Aquino \& M. J. Rosado-Nunes (Eds.), Feminist Intercultural Theology: Latina Explorations for a Just World. Maryknoll: Orbis Books, pp. 9-28. 
Arrazola, A. A. (2011). Deconstructing the Religious Archive and its Secular Component and its Relationship to Violence. Master of Arts, Florida International University, Miami, FL.

Bain, K. (2011). Socioeconomic Status in Early Christianity and Thecla's Rejection of Marriage. Journal of Feminist Studies in Religion, 27(2), 51-69.

Baines, D. (2010). Gender Mainstreaming in a Development Project: Intersectionality in a Post-Colonial Un-doing? Gender, Work and Organization, 17(2), 119-149.

Barager, J. (2009). From the Periphery Toward the Center 1: Locating an Alternative Genealogy for Disability Studies in Audre Lorde's The Cancer Journals Thinking Gender Papers. Los Angeles: UCLA Center for the Study of Women.

Bastia, T. (2011). Migration as protest? Negotiating gender, class, and ethnicity in urban Bolivia. Environment and Planning A, 43(7), 1514-1529.

Bobel, C., \& Kissling, E. A. (2011). Menstruation Matters: Introduction to Representations of the Menstrual Cycle. Women's Studies, 40(2 ), 121-126.

Brown, M. (2011). Gender and sexuality I: Intersectional anxieties. Progress in Human Geography, 36(4), 541-550.

Bruns, C. M. (2010). Feminism and Feminist Therapy Across Generations. Women \& Therapy, 34(1-2), 19-37.

Buckingham, S., \& Kulcur, R. (2009). Gendered Geographies of Environmental Justice. Antipode, 41(4), 659-683.

Buell, D. K. (2010). Cyborg Memories: An Impure History of Jesus. Biblical Interpretation, 18(4), 313-341.

Bürkner, H.-J. (2011). Intersectionality: How Gender Studies Might Inspire the Analysis of Social Inequality among Migrants. Population, Space and Place, 18(2), 181-195.

Campbell, H. (2006). Just Planning: The Art of Situated Ethical Judgment. Journal of Planning Education and Research, 26(1), 92-106.

Cole, E. R. (2009). Intersectionality and research in psychology. American Psychologist, 64(3), 170-180.

Collins, P. H. (1998a). Fighting Words: Black Women and the Search for Justice. Minneapolis, MN: University of Minnesota Press.

Collins, P. H. (1998b). It's All In the Family: Intersections of Gender, Race, and Nation. Hypatia, 13(3), 62-82.

Collins, P. H. (2000). Black Feminist Thought: Knowledge, Consciousness, and the Politics of Empowerment ( $2^{\text {nd }}$ ed.). New York, NY: Routledge.

Connolly, J., \& Steil, J. (2009). Introduction: Finding justice in the city. In P. Marcuse, J. Connolly, J. Novy, I. Olivo, C. Potter \& J. Steil (Eds.), Searching for the Just City: Debates in urban theory and practice. London: Routledge, pp. 1-16.

Couch, J. (2011). A new way home: Refugee young people and homelessness in Australia. Journal of Social Inclusion, 2(1), 39-52.

Crenshaw, K. (1989). Demarginalizing the Intersection of Race and Sex: A Black Feminist Critique of Antidiscrimination Doctrine, Feminist Theory and Antiracist Politics. The University of Chicago Legal Forum, 1989, 139-167.

Crenshaw, K. (1991). Mapping the Margins: Intersectionality, Identity Politics, and Violence against Women of Color. Stanford Law Review, 43(6), 1241-1299.

Crosby, E. D. (2011). A Quiver Full of Mommy Blogs: Ideological Subversion and Reinforcement of Mothering Models Online. Master of Arts, Indiana University, IN.

Derickson, K. D. (2009). Gendered, material, and partial knowledges: a feminist critique of neighborhood-level indicator systems. Environment and Planning A, 41(4), 896-910.

Dias, K., \& Blecha, J. (2007). Feminism and Social Theory in Geography: An Introduction. The Professional Geographer, 59(1), 1-9. 
Dilling, L., \& Moser, S. C. (2007). Introduction. In S. C. Moser \& L. Dilling (Eds.), Creating a climate for change: communicating climate change and facilitating social change. Cambridge: Cambridge University Press, pp. 1-27

Doan, P. L., \& Higgins, H. (2011). The Demise of Queer Space? Resurgent Gentrification and the Assimilation of LGBT Neighborhoods. Journal of Planning Education and Research, 31(1), 6-25.

Donner, W., \& Rodríguez, H. (2008). Population Composition, Migration and Inequality: The Influence of Demographic Changes on Disaster Risk and Vulnerability. Social Forces, 87(2), 1089-1114.

Fainstein, S. S. (2000). New Directions in Planning Theory. Urban Affairs Review, 35(4), 451-478.

Fainstein, S. S. (2009). Planning and the Just City. In P. Marcuse, J. Connolly, J. Novy, I. Olivo, C. Potter \& J. Steil (Eds.), Searching for the Just City: Debates in urban theory and practice. London: Routledge, pp. 19-39.

Fainstein, S. S., \& Servon, L. J. (2005). Introduction: The Intersection of Gender and Planning. In S. S. Fainstein \& L. J. Servon (Eds.), Gender and Planning: a reader. New Brunswick, NJ: Rutgers University Press, pp. 1-12.

Fischer, F. (2009). Discursive planning: Social justice as discourse. In P. Marcuse, J. Connolly, J. Novy, I. Olivo, C. Potter \& J. Steil (Eds.), Searching for the Just City: Debates in urban theory and practice. London: Routledge, pp. 52-71.

Fisher, S. (2010). Violence Against Women and Natural Disasters: Findings From PostTsunami Sri Lanka. Violence Against Women, 16(8), 902-918.

Friberg, T. (2006). Towards a gender conscious counter-discourse in comprehensive physical planning. GeoJournal, 65(4), 275-285.

Friedmann, J. (2003). Why do planning theory? Planning Theory, 2(1), 7-10.

Frisch, M. (2002). Planning as a Heterosexist Project. Journal of Planning Education and Research, 21(3), 254-266.

Frye, V., Putnam, S., \& O'Campo, P. (2008). Whither gender in urban health? Health and Place, 14(3), 616-622.

Fuchs, E. (2008). Biblical Feminisms: Knowledge, Theory and Politics in the Study of Women in the Hebrew Bible. Biblical Interpretation, 16(3), 205-226.

Haniff-Cleofas, R., \& Khedr, R. (2005). Women with Disabilities in the Urban Environment, National Network on Environments and Women's Health. Toronto, ON: National Network on Environments and Women's Health.

Healey, P. (2006). Collaborative Planning: Shaping Places in Fragmented Societies (2nd Edition). Houndmills: Palgrave Macmillan.

Hendler, S. (1994). Feminist Planning Ethics. Journal of Planning Literature, 9(2), 115-127.

Hill, F. D. (2008). Disarming the "Bible-bashers": Claiming the Bible for Australian Abuse Survivors. Doctor of Philosophy, Melbourne College of Divinity, Melbourne, Australia.

Hoernig, H. (n.d.). Lessons from recent immigrant, minority place of worship development for urban planning amidst cultural diversity. Available at: http://canada.metropolis.net/pdfs/Heidi_Hoernig_e.pdf

hooks, b. (1982). Ain't I A Woman: Black Women and Feminism. London: Pluto Press.

hooks, b. (1989). Talking Back: thinking feminist, thinking black. Cambridge, MA: South End Press.

hooks, b. (2000a). Feminism is for everybody: passionate politics. London: Pluto Press. hooks, b. (2000b). Feminist theory: from margin to center (2nd ed.). London: Pluto Press. Hopkins, P. (2008). Critical Geographies of Body Size. Geography Compass, 2(6), 21112126. 
Hopkins, P. (2011). Everyday Politics of Fat. Antipode, 44(4), 1227-1246.

Hunt, M. E. (2001a). Designer Theology: A Feminist Perspective. Zygon, 36(4), 737-751.

Hunt, M. E. (2001b). Queering Old Time Religion. Literature \& Theology, 15(3), 210-223.

Isherwood, L. (2011). Dancing Theology on Earthquakes: Trends and Direction in Feminist Theologies. The Expository Times, 122(4), 157-166.

Jaggar, A. M. (2004). Feminist Politics and Epistemology: The Standpoint of Women. In S. Harding (Ed.), The Feminist Standpoint Theory Reader: Intellectual and Political Controversies. New York: Routledge, pp. 55-66.

Kang, N. (2005a). The Centrality of Gender Justice in Prophetic Christianity and the Mission of the Church Reconsidered. International Review of Mission, 94(373), 278-289.

Kang, N. (2005b). A 'Transit Home' Away from Home. Journal of Feminist Studies in Religion, 21(2), 123-126.

Kartzow, M. B. (2010). "Asking the Other Question": An Intersectional Approach to Galatians 3:28 and the Colossian Household Codes. Biblical Interpretation, 18(4-5), 364-389.

Kienzle, B. M., \& Nienhuis, N. (2001). Battered Women and the Construction of Sanctity. Journal of Feminist Studies in Religion, 17(1), 33-61.

Kim, N., \& Whitehead, D. (2009). Elisabeth Schüssler Fiorenza and Feminist

The*logies/Studies in Religion. Journal of Feminist Studies in Religion, 25(1), 1-18.

Kirk, G. (1997). Ecofeminism and Environmental Justice: Bridges across Gender, Race, and Class. Frontiers: A Journal of Women Studies, 18(2), 2-20.

Lee, J.-A. (2007). Gender, Ethnicity, and Hybrid Forms of Community-Based Urban Activism in Vancouver, 1957-1978: The Strathcona story revisited. Gender, Place \& Culture, 14(4), 381-407.

LeFrançois, B. A. (2013). Queering Child and Adolescent Mental Health Services: The Subversion of Heteronormativity in Practice. Children \& Society, 27(1), 1-12.

Lelwica, M., Hoglund, E., \& McNallie, J. (2009). Spreading the Religion of Thinness from California to Calcutta: A Critical Feminist Postcolonial Analysis. Journal of Feminist Studies in Religion, 25(1), 19-41.

Levine, J. N., Esnard, A.-M., \& Sapat, A. (2007). Population Displacement and Housing Dilemmas Due to Catastrophic Disasters. Journal of Planning Literature, 22(3), 3-15.

Listerborn, C. (2007). Who speaks? And who listens? The relationship between planners and women's participation in local planning in a multi-cultural urban environment. GeoJournal, 70(1), 61-74.

Lorde, A. (1984). Sister Outsider: Essays and Speeches by Audre Lorde. Berkeley, CA: The Crossing Press.

Maddison, S., \& Scalmer, S. (2006). Activist Wisdom: Practical Knowledge and Creative Tension in Social Movements. Sydney: UNSW Press.

Marchal, J. A. (2006). Imperial Intersections and Initial Inquiries: Toward a Feminist, Postcolonial Analysis of Philippians. Journal of Feminist Studies in Religion, 22(2), 5-32.

Marcuse, P., Connolly, J., Novy, J., Olivo, I., Potter, C., \& Steil, J. (Eds.). (2009). Searching for the Just City: Debates in urban theory and practice. London: Routledge.

Marris, P. (1998). Planning and Civil Society in the Twenty-first Century: An Introduction. In M. Douglass \& J. Friedmann (Eds.), Cities for Citizens: Planning and the Rise of Civil Society in a Global Age. Chichester: John Wiley \& Sons Ltd., pp. 9-17.

Masenya, M. J. (1995). African Womanist Hermeneutics: A Suppressed Voice from South Africa Speaks. Journal of Feminist Studies in Religion, 11(1), 149-155.

Matsuda, M. J. (1991). Beside My Sister, Facing the Enemy: Legal Theory Out of Coalition. Stanford Law Review, 43(6), 1183-1192. 
Milroy, B. M. (1991). Taking Stock of Planning, Space, and Gender. Journal of Planning Literature, 6(1), 3-15.

Miraftab, F. (2009). Insurgent Planning: Situating Radical Planning in the Global South. Planning Theory, 8(1), 32-50.

Moon, H. (2008). Womenpriests: Radical Change or More of the Same? Journal of Feminist Studies in Religion, 24(2), 115-134.

Moretti, C. (2008). A Walk with Two Women: Gender, Vision and Belonging in Milan, Italy. In J. N. DeSena (ed.), Gender in an Urban World: Research in Urban Sociology. Emerald Group Publishing Ltd., pp. 53-75.

Moxnes, H. (2010). Identity in Jesus' Galilee - From Ethnicity to Locative Intersectionality. Biblical Interpretation, 18(4), 390-416.

Neumayer, E., \& Plümper, T. (2007). The Gendered Nature of Natural Disasters: The Impact of Catastrophic Events on the Gender Gap in Life Expectancy, 1981-2002. Annals of the Association of American Geographers, 97(3), 551-566.

Nieves, A. D. (2002). "With them the Pen Must be Mightier than the Sword": Writing, Engendering, and Racializing Planning History. Journal of Planning History, 1(3), 215-219.

Nightingale, A. J. (2011). Bounding difference: Intersectionality and the material production of gender, caste, class and environment in Nepal. Geoforum, 42 (2), 153-162.

Peattie, L. R. (1994). Communities and interests in advocacy planning. Journal of the American Planning Association, 60(2), 151-153.

Powell, L. D. (2011). Sor Juana's Critique of Theological Arrogance. Journal of Feminist Studies in Religion, 27(2), 11-30.

Power, T. (2001). Dancing on a Moving Floor: Lay Women and the Principalship in Catholic Education. Doctor of Education, Deakin University, Australia.

Preston, J., Avery, B., Chakrabarty, N., \& Edmonds, C. (2011). Emergency preparedness as public pedagogy: the absent-presence of race in 'Preparing for Emergencies'. International Journal of Lifelong Education, 30(6), 749-762.

Quinn, K. (2002). Planning History/Planning Race, Gender, Class, and Sexuality. Journal of Planning History, 1(3), 240-244.

Rankin, K. N. (2009). Critical development studies and the praxis of planning. City, 13(2-3), 219-229.

Reed, M. G., \& Mitchell, B. (2003). Gendering environmental geography. Canadian Geographer / Le Géographe canadien, 47(3), 318-337.

Sandercock, L. (1998a). The Death of Modernist Planning: Radical Praxis for a Postmodern Age. In M. Douglass \& J. Friedmann (Eds.), Cities for Citizens: Planning and the Rise of Civil Society in a Global Age. Chichester: John Wiley \& Sons Ltd., pp. 163184.

Sandercock, L. (1998b). Towards Cosmopolis: Planning for Multicultural Cities. Chichester: John Wiley \& Sons Ltd.

Sandercock, L. (2003). Cosmopolis II: Mongrel Cities in the 21st Century. London: Continuum.

Sandercock, L., \& Forsyth, A. (1992). A Gender Agenda: New Directions for Planning Theory. Journal of the American Planning Association, 58(1), 49-59.

Schneider, L. C., \& Trentaz, C. J. E. (2008). Making Sense of Feminist Theology Today. Religion Compass, 2(5), 788-803.

Schüssler Fiorenza, E. (1992). But She Said: Feminist Practices of Biblical Interpretation. Boston, MA: Beacon Press. 
Schüssler Fiorenza, E. (2005). Feminist Studies in Religion and the The*logy In-Between Nationalism and Globalization. Journal of Feminist Studies in Religion, 21(1), 111119.

Sismondo, S. (2001). Standpoint Theory, in Science. In N. J. Smelser \& P. B. Baltes (Eds.), International Encyclopedia of the Social and Behavioral Sciences. Online: ScienceDirect, pp. 14952-14955.

Speak, S. (2012) Planning for the needs of the urban poor in the Global South: The value of a feminist approach. Planning Theory 11(4): 343-360.

Spinks, C. C. (2010). Body Politics within the Body Politic: Ghanaian Disabled Communities and Their Relationships to Power. ISP Collection, Paper 912. Available at http://digitalcollections.sit.edu/isp_collection/912 (accessed 18 November 2011).

Steele, W., MacCallum, D., Byrne, J., \& Houston, D. (2012). Planning the Climate-just City. International Planning Studies, 17(1), 67-83.

Sultana, F. (2010). Living in hazardous waterscapes: Gendered vulnerabilities and experiences of floods and disasters. Environmental Hazards, 9(1), 43-53.

Thompson, J. P. (2009). Race in New Orleans since Katrina. In P. Marcuse, J. Connolly, J. Novy, I. Olivo, C. Potter \& J. Steil (Eds.), Searching for the Just City: Debates in urban theory and practice. London: Routledge, pp. 214-228.

Tompkins, E. L., \& Adger, W. N. (2003). Building resilience to climate change through adaptive management of natural resources Working Paper 27. Norwich, UK: Tyndall Centre for Climate Change Research, University of East Anglia.

Valentine, G. (2007). Theorizing and Researching Intersectionality: A Challenge for Feminist Geography. The Professional Geographer, 59(1), 10-21.

Verick, S. (2009). Who is Hit Hardest During a Financial Crisis? The Vulnerability of Young Men and Women to Unemployment in an Economic Downturn. IZA Discussion Paper No. 4359. Bonn, Germany: IZA.

Walby, S. (2001). Against Epistemological Chasms: The Science Question in Feminism Revisited. Signs: Journal of Women in Culture and Society, 26(2), 485-509.

Walter, R. A. (2010). How Queer Stays White: A Program that Addresses White and Male Supremacy in Queer Struggle. In R. Scales, R. Walter, M. Chevalier, A. Moncrief \& C. White (Eds.), Mosaic: A Journal of Original Research on Multicultural Education, Teaching, and Learning (Vol. 3). Fairfax, VA: George Mason University Multicultural Research and Resource Centre Publication, pp. 1-12.

Watson, A. (2009). Being Inappropriate: Queer Activism in Context. Master of Arts, Central European University, Budapest.

Watson, B., \& Ratna, A. (2011). Bollywood in the park: thinking intersectionally about public leisure space. Leisure/Loisir, 35(1), 71-86.

Wright, M. W. (2010). Gender and geography II: bridging the gap - feminist, queer, and the geographical imaginary. Progress in Human Geography, 34(1), 56-66.

Wylie, A. (2003). Why Standpoint Matters. In R. Figueroa \& S. Harding (Eds.), Science and Other Cultures: Issues in Philosophies of Science and Technology. New York, NY: Routledge, pp. 26-48.

Yamin, F., Rahman, A., \& Huq, S. (2005). Vulnerability, Adaptation and Climate Disasters: A Conceptual Overview. Institute of Development Studies Bulletin, 36(4), 1-14.

Yiftachel, O. (1998). Planning and Social Control: Exploring the Dark Side. Journal of Planning Literature, 12(4), 395-406.

Young, I. M. (2005). Justice and the Politics of Difference. In S. F. Fainstein \& L. J. Servon (Eds.), Gender and Planning: a reader. New Brunswick: Rutgers University Press, pp. 86-103. 